\title{
Blue Tunics and Batons: Women and Politics in the Queensland Police, 1970-1987
}

\section{Tim Prenzler and Kerry Wimhurst}

During the 1970s and 1980s, policewomen in Queensland experienced dramatic changes of fortune under two different commissioners. Under Commissioner Whitrod (1970-76), the percentage of policewomen went from below the Australian national average to twice the national average, and women were integrated into general duties and the seniority list. Women in Queensland began entering policing in large numbers at a time when those in overseas jurisdictions and other Australian states were struggling in small numbers to make inroads. In the period immediately following, under Commissioner Lewis (1976-87), the proportion of women police was cut to almost half the national average.

This paper analyses the changes that took place in the recruitment and career experiences of policewomen during these years. Minimum standards for changing the work conditions and career prospects of women are proposed from this case study. Queensland did not have anti-discrimination and equal opportunity legislation at this time and this article argues that such legislation is an essential first step to securing basic rights. The paper acknowledges some of the weaknesses of current liberal-democratic legislation and practices, but also points to the powerful symbolic role of such legislation. In addition, it seems that anti-discrimination policies and practices encounter particular problems in policing where women themselves often remain wary of resorting to grievance procedures. It is clear from the study that when women are integrated in large numbers into a male dominated organisation, direct and indirect discrimination against them will take a heavy toll. Comprehensive support mechanisms are needed when such an organisation is opened to female entry.

Conditions for women police during the period under review were determined largely by the discretionary powers of senior officers. This can work to a limited extent in favour of women under a progressive administration. Nonetheless, in the long term, this is an unreliable source of equal treatment. The study will demonstrate that during times of progressive organisational change in police agencies, direct and indirect discrimination against women persisted. An important finding of this study is that discrimination can in part result from the unrealistic expectations that progressives hold for the professionalising influence of women during times of reform. ${ }^{1}$

Major overseas studies reveal that women entering law enforcement this century have usually met with hostility, discrimination and harassment. ${ }^{2}$ The literature continues to portray entrenched male antagonism towards women entrants in policing. Balkin, for example, shows that many men feel psychologically threatened by the presence of female colleagues because the masculinised world of policing becomes increasingly destabilised as women disrupt the 'natural order'. ${ }^{3}$ Hunt claims that male opposition arises from their anxieties about the supposed moral superiority of women police. ${ }^{4}$ One recent study shows that about one-third of men in the 1990s still oppose working with women in day-to-day patrol situations, ${ }^{5}$ and this negativity 
has been confirmed by Austin and Hummer's findings that one-third to one-half of the college criminal justice majors in their survey held negative attitudes towards female officers. ${ }^{6}$

There are, however, studies which suggest that while opposition to women might be an accurate portrayal of the past, contemporary and future conditions for women police are more promising. This view is based on empirical data which often discloses relatively few differences between the current experiences of men and women. ${ }^{7}$ Love and Singer, for example, found that while women police in New Zealand felt some concern about their capacity to handle violent situations, no gender differences were apparent on other measures of psychological well-being or job satisfaction. ${ }^{8}$ Worden asserts that while women have been discriminated against, and still have yet to be integrated fully into American policing, there are few differences in the ways male and female officers view their role, the community, or their colleagues. ${ }^{9}$

On the whole, cautious optimism characterises the leading studies in the field. ${ }^{10}$ There is a recognition that major legislative and organisational changes have removed formal barriers to women but concern remains over the slow pace of change towards cultural integration and numerical equality. Heidensohn, for example, notes that women have clearly demonstrated their commitment to police work and have moved away from the more limited 'social worker in uniform' constraints that characterised their role earlier this century. However, she also notes a 'core masculine opposition' that remains reluctant to share power with women, particularly when that involves power over other men — whether internal or external to police organisations. ${ }^{11}$ Other notes of frustration include the observation that still relatively few women enter policing and constitute only just over $10 \%$ of the total sworn strength in most agencies. In addition, local and overseas experiences suggest that rank is no protection against harassment. A number of reported recent cases involved the harassment of senior women by male colleagues. ${ }^{12}$ The struggle against harassment has emerged as a major area of conflict in police services. Some studies suggest that up to two-thirds of women police experienced some form of sexual harassment from a co-worker or supervisor, but that many did not take action to address the situation. ${ }^{13}$

The following study finds that women confronted much discrimination during the administrations of two very different police commissioners in Queensland in the 1970s and 1980s. Irrespective of whether the administration was progressive or reactionary, there was always the sense that the entry of women into agencies of formal social control would create fundamental changes, both in policing and wider society. ${ }^{14}$ Among stakeholders, there was the hope by a few progressive elements that the integration of women might make policing more professional and accountable. Conservative factions were fearful that these expectations might be true. These competing political and professional agendas have been the powerful underlying currents shaping the variable experiences of women officers. Progressives and conservatives held simultaneously positive and negative beliefs about the consequences of the feminisation of policing. Thus, women were discriminated against under very different regimes partly because they were unrealistically charged with tremendous power.

During the 1970s and 1980s Queensland was controlled by the conservative National Party and was often referred to as 'the Deep North'. Over a period in 
which virtually all other Australian states and the federal government were at times led by Labor, the conservatives in Queensland managed to capture and construct the ground of social policy formulation in almost uncontested terms. ${ }^{15}$ The conservatives were able to appeal to both transnational capitalism (the tourism and mining booms) as well as the conservatism of rural voters. A system of zonal malapportionment of parliamentary seats assisted the rural-based National Party to stay in power and dominate its Liberal Party coalition partner. ${ }^{16}$ Queensland was portrayed as the last bastion of free-enterprise and family-based values which stood almost alone against the 'socialists' in the southern states. Conservatives in Queensland were able to delay the introduction of commonwealth social justice initiatives by claiming that they are defending states rights' against federal government encroachment. An ideology of states' rights insulated Queensland from progressive social change occurring elsewhere in Australia. Although the federal government and most states enacted anti-discrimination legislation, Queensland remained without basic legislative provisions for equality of opportunity. Matters relating to women were determined (or ignored) in an environment which mixed both paternalist and laissez-faire governance. In addition, life could be menacing for those who opposed the regime. Putnis refers to the sense of 'thinly disguised coercion' that characterised the state. ${ }^{17}$ For much of the period under review, the police were used unabashedly as an instrument of coercion when the government felt itself threatened. ${ }^{18}$

Yet it is important not to over-emphasise Queensland's 'difference'. The political and social environment described might well explain why anti-discrimination legislation, for example, was so late in arriving. But, certainly in the case of women police, there is little to suggest that the experiences described in this study were (and are) markedly different elsewhere. Rather, Queensland can be seen as a case study which captures in a fairly extreme form the difficult conditions experienced by women police over the past twenty-five years as they attempted to cope with the conflicting expectations of competing political agendas.

The Whitrod years between 1970-1976 were described by a former policewoman as a 'Camelot for women police because of the apparent opening of opportunities'. In 1969 there were only 22 women in a police force of over 3,220 sworn officers. These women worked within a narrow band of secretarial and welfare-oriented duties. Most of them were confined to a Police Women Section attached to the Criminal Investigation Branch in Brisbane. In 1970 that situation changed dramatically when Ray Whitrod, a South Australian, was appointed commissioner. At first Whitrod was encouraged by the conservative government to improve the image of what was seen to be an out-dated and inefficient police force. He immediately set about a radical restructuring of the force including decentralising many operations, boosting rapid mobile responses and upgrading education.

During the six years when Whitrod was commissioner the number of female officers increased rapidly to a peak of $8.5 \%$ of sworn personnel (10\% when trainees were included). By the mid-1970s it appeared that a new era had arrived for women. It was claimed that Queensland had the highest percentage of women police in the western world. ${ }^{19}$ Whitrod was directly responsible for opening the recruiting process by accepting female applications as a matter of routine and encouraging selectors to take on women. 
The move to recruit more women was initially prompted by a shortage of suitable male applicants. Women were also recruited because they were better qualified than male applicants and suited Whitrod's goal of 'procuring intelligence' ${ }^{20}$ It is apparent, nonetheless, that Whitrod soon went beyond merely opening the doors. He saw the employment of women as a crucial strategy in professionalising the police and boosting efficiency. They were seen by a reforming commissioner as constituting a means of 'political' incursion into the male domain of the 'old guard' of the police force. He did not see his actions as part of a wider drive for social justice and gender equity: 'They were not appointed because they were females. It was a recruitment policy to get the best possible person'. ${ }^{21}$ As part of his strategy for reform, the commissioner continued to extol the professionalism and integrity of the new women officers. He vigorously defended the expanded recruitment program, especially in his fortnightly newsletter where he reported on developments in the employment of policewomen in Australia and overseas. He congratulated women whenever they excelled in various aspects of police work, using the cases as examples of the professional capabilities of women.

Under Whitrod, a variety of organisational reforms were introduced which favoured women. The Police Women Section was disbanded and female officers were integrated into regular squads and into the one seniority list along with men. Whitrod removed the marriage bar, introduced accouchement leave, and assisted the union to obtain equal pay for women. In the past, adult women had been trained as probationary constables, but now younger women were allowed to train at the academy as cadets. Whitrod had a strong interest in victimology and established a rape squad staffed by women to provide a more empathetic response to rape victims. The creation of the squad also meant that female members could obtain the necessary training and experience to interview rape victims and give evidence in court.

Despite such organisational reforms, it was never envisaged that women might need special support to carry through the political and professional agenda that their commissioner had set for them. Whitrod later expressed regret that he did not give more encouragement to experienced women to seek promotion and act as mentors for others. He recorded that 'the old guard set of values remained largely unchallenged except for a few exceptional women officers who were prepared to buck the system. It may have been my fault in that I did not have enough time to give to their personal development, and they had no role model to follow'.

After over a century of working with their own kind, male officers were suddenly faced with a new type of partner. Integration provoked widespread resistance. Discrimination took various forms including pejorative comments, lack of co-operation and differential assignment. As one woman recalled:

There was a lot of reluctance to even work with women. When we first went to the station the natural response from the senior sergeant was to put you straight on counter duties where you issued licenses and took reports and lost property ... There was a feeling that women couldn't do the job properly. We weren't as strong, we couldn't run as fast, we couldn't drive as well ... A lot of the men had an opportunity to choose between a male and a female partner. They'd pick the male partner. That was fairly common, even the female officer doing the late shift would be at the station doing some typing or answering the phones while her partner was out in the 
car. $^{24}$

Apart from the presumption that policewomen were meant for office duties, the probationary constables in particular also had to contend with various forms of sexual harassment. Interviewees for this study claimed that sexual harassment was generally minor in nature, although its effects ranged from irritating to distressing. It appears that most perpetrators were easily dissuaded when women resisted: 'Others used to just cop it and go home and cry in frustration because they weren't going to say anything and get badmouthed around the station'. ${ }^{25}$

A common form of discrimination was chivalrous over-protection, often wellintentioned, but discrimination nonetheless. While the commissioner had opened the door to female mobility within the police force, women still had to insist on fair treatment, especially where over-protection denied them opportunities to develop operational skills. ${ }^{26}$ For example, although there was considerable civil unrest during this period, it was assumed that women would be excused from field training in tear gas situations - until some of them insisted on proper training.

The police union played an ambivalent role in the progress of women officers. While helping them to achieve basic parity in some areas during the 1950s and 1960s — and thus also ensuring that conditions for men were not undercut - the union became less supportive when the influx of women in the early 1970s potentially threatened the balance of power between male and female officers. The union had been stridently opposed to the appointment of policewomen early in the century (first achieved in 1931). Women were allowed to join the union in 1955 and the union supported a limited role for policewomen in welfare-related duties. It advocated the appointment of women to all district headquarters to work with women and girls. ${ }^{27}$ It also was active in support of equal powers for policewomen (achieved in 1965), and equal pay, superannuation rights and overtime. For a while, prior to the appointment of Whitrod, the union even argued that women could be put into the full range of duties, but this stance was highly unusual and short lived. ${ }^{28}$

By 1972 anxieties began to be expressed about the number of women being recruited at what was thought to be the expense of males. There was also concern expressed about women in patrol cars and on night duty and a deputation from the executive met with Whitrod over the matter. ${ }^{29}$ A story circulated widely about a policewoman at a hotel brawl who allegedly abandoned her male partner, locked herself in the patrol car and cried while her partner was assaulted. The police union voiced concern over the alleged incident but Whitrod was unable to verify any cases of female dereliction of duty. ${ }^{30}$ Many rank and file officers felt that equal pay should mean equal work and they did not mind shifting some of the unpleasantness of night duty to women. ${ }^{31}$ Union president Ron Edington was less enthusiastic. He was reported in the press as saying that there was a crime wave caused by lack of male officers and too many 19 year old 'Ainsley Gottos ... joining the force on $\$ 4,200$ a year to buy their trousseaus'. Whitrod was accused of hiding staffing problems 'behind policewomen's skirts'. ${ }^{32}$

Whitrod resigned suddenly near the end of 1976 . He had become locked into an ongoing battle with the police union and the government over his modernisation policies. Conflict came to a head after the conservative cabinet and the premier 
overrode Whitrod's directive for an investigation into an alleged police bashing of a street demonstrator. In addition, a backlash against women officers was occurring. By 1976, before Whitrod resigned, female intakes were reduced with a view to stabilising the number of policewomen at about $10 \%{ }^{33}$ Whitrod has said that he cannot recall this but felt that a slowing down may have been instigated to reduce internal controversy. ${ }^{34}$

Compounding the backlash was the (re-)emergence of a group of senior officers who were antagonistic to the wider agenda for reform and the ambitions of women police. The appointment of Inspector Terence Lewis as assistant commissioner, against Whitrod's wishes, was the final frustration for Whitrod - who had earlier banished Lewis to a country town because he suspected corruption. ${ }^{35}$ It has been argued that the mistrust of women shown by these men also emerged because they suspected that women were much less susceptible to misconduct and corruption ${ }^{36}$. Allegations of corruption were a persistent feature of policing in Queensland - as in other states. Prominent in the allegations from the late 1950s was a group of officers known as the 'rat pack'. It was alleged that membership of this group included such senior officers as Terry Lewis and Tony Murphy. Although Lewis was later to be imprisoned for corruption, allegations against Murphy were never substantiated. ${ }^{37}$ From his posting in the country, Lewis cultivated political connections of sufficient strength to enable him to be promoted to commissioner upon Whitrod's resignation. Under Lewis, Murphy became an assistant commissioner.

With Lewis supporting the government on law and order issues, the police were left unaccountable in many areas of administration. The 'old guard' clearly saw that the widespread recruitment and deployment of women was an important part of the reform agenda of their former rival. When this group promised a new era in policing in Queensland it was a pre-Whitrod model that they had in mind, one in which women would again take a low profile. Whitrod's resignation was viewed by many women with dismay:

People like myself and other people who came in as cadet women at that time believed the rhetoric of Ray (Whitrod), that he was there to create a professional police agency ... And then when he bailed out prematurely, as I saw it, he left us to the wolves. ${ }^{38}$

Over the following decade, women's career prospects were crippled as they continued to be identified as 'Whitrod's princesses' and thus they were always seen as potentially disruptive agents of organisational and professional change.

The most obvious damage done in the Lewis years was the decimation of policewomen numbers by drastic cutbacks in recruitment. The change in the percentage of women police fell from well above the Australian average in 1976 to well below the national average a decade later. The recruitment of female cadets (school leavers) was halted in 1978 and female entry was restricted to a small quota of female probationaries (adult entrants). For almost a decade through until the mid 1980s the number of probationaries remained at about two per squad of 25 . At times, two women per 50 men were recruited. The number of policewomen reached 
a low of $5.2 \%$ in $1989 .{ }^{39}$ The explanation provided by the police force was that recruiting and training women was a waste of resources. In 1977 the Planning and Research Branch of the force produced a report on policewomen which showed high attrition rates. It was claimed that this was used as a rationale for reducing the number of female recruits. ${ }^{40}$

There is no evidence that either incompetence or dissatisfaction with the job caused women to leave. Moreover, there was always a surplus of qualified women applicants waiting to enter policing. Rather, marriage and starting a family were frequently cited reasons for leaving (accouchement leave was only six months). High resignation rates by males had been an issue throughout the Whitrod years, but women themselves were blamed for the high female rate. ${ }^{41}$ There is evidence that women making enquiries about recruitment were dissuaded from applying by a lack of encouragement. One officer who joined in 1979 remembers:

I wanted to get in the air force and at the same time I went down and tried to get
into the police as well to improve my options and they said they couldn't give out an
application for a start, but I persisted and they said, 'well okay here's an application
form and if you haven't heard from us in 12 months give us a call.' So I was very
disillusioned. So I just started ringing them and talking to them and going back. ${ }^{42}$

Commissioner Lewis's fixation with the 'problem' of women police is apparent in his diary entries made over the duration of his administration. One entry made within the first year of his assumption of power states baldly: 'Policewomen integration not really successful' ${ }^{43}$ Lewis rejected requests for policewomen to be posted to one-person stations, stating that he thought policewomen did not have the same role as policemen. ${ }^{44} \mathrm{He}$ also requested regular statistical reports showing the declining number of policewomen. ${ }^{45}$ The commissioner's view of women appeared to soften for a short time when his own daughter reached recruitment age. She was invalidated out of the force after a short period. There is some question about whether Lewis was genuinely misogynist, or whether his actions flowed from the political compromises he was able to strike with other senior officers within the police department and the police union. ${ }^{46}$ The influence of the police union was probably critical. Union hostility was a major factor in the demise of Whitrod, and Lewis was quick to make peace with the powerful group. ${ }^{47}$ Although Lewis did not restrict policewomen's duties to the extent that had been demanded by the union in its approaches to Whitrod, the cutbacks placated the union on the issue.

In face-to-face situations Lewis appeared to be very supportive of women police. He commonly telephoned them or sent notes to congratulate them on various achievements. Occasionally a woman through her talent and tenacity was promoted to sergeant. More often, limited mobility occurred with little chance for women to be promoted to commissioned officer rank. The advancements that were made were a result of the seniority system, the flow through of women who joined in the Whitrod years and the need for senior (but non-commissioned) officers in traditional 'female' deployments. Given the attrition of women in the late 1970s, there were few candidates even for sergeant positions by the 1980s.

Women officers were aware of, and most were concerned about, the cutbacks but they also felt helpless. There were no senior women at commissioned officer 
level who might have had an influence on policy. One interviewee recalls that 'the girls we did have as sergeants weren't active, so nothing was done. We all used to have a whinge between ourselves, until we decided that the situation was beyond our control'. ${ }^{48}$

Along with the cutbacks, women officers were directly intimidated. One of Lewis' more notorious actions was a 'terror campaign' involving the interrogation of policewomen about their alleged sexual inclinations and affairs. As noted by other commentators, a particularly virulent form of attack on women police is one which is directed at their sexuality and sexual preferences. ${ }^{49}$ Such harassment, of course, usually occurs on an informal and uncoordinated basis in the work place. However, in the case of the 'lesbian witch-hunt', the attack was raised to the level of a formal inquisition conducted by senior members of the police hierarchy.

In 1977-78 Tony Murphy and another senior officer investigated an alleged 'lesbian cell' of policewomen who purportedly openly displayed their homosexuality in Brisbane nightclubs. ${ }^{50}$ At least seven women were interrogated and threatened with exposure of their sexuality and with forced relocation to other parts of the state. The threats of transfer and disclosure were designed to intimidate women into resigning and some women did resign rather than be transferred away from their partners. The next best option for the inquisitors was to use transfers as a way of breaking up relationships and a number of women were transferred out of Brisbane. It is not clear that any officer's family was told by officialdom that their daughter was a lesbian but some of the women were provoked into telling their families. ${ }^{51}$

From October 1977 Lewis's diaries contain a number of cryptic references to the investigations. For example:

Saw A/C McIntyre re several P/Women suspected of being lesbians (5-10-77).

Supt. Murphy phoned re lesbian inquiry ... Saw Messrs C. Chant and T. Mahon re lesbian P/Women approaching Union, and some of their allegations (23-12-77).

Saw Supt. Murphy re ... and lesbian P/women (24-3-78).

Saw Supt. Murphy re reports on lesbian p/women (27-6-78)

With $\mathrm{p} / \mathrm{w}$... discussed duties, ... and lesbian p/women until 7 pm (12-7-78).

The national press saw the witch-hunt as part of a revived crusade against homosexuals in conservative Queensland. A truce had existed between the homosexual community and the police during the Whitrod years. Now, the media claimed, 'the conservative Catholic hierarchy of the force, headed by Commissioner Terry Lewis and the CIB chief, Superintendent Tony Murphy, has turned its law-enforcing eye on the moral well-being of the State'. ${ }^{52}$ But there was more at stake than a homophobic counterattack or moral crusade. The press was equally certain that the interrogation of homosexual females was an attempt 'to reduce both the numbers and the influence of policewomen in Queensland'.

From November 1978 until October 1980, Lewis personally interviewed female applicants for recruitment. It now seems bizarre that the state's most senior officer should take it upon himself to screen applicants but his diaries indicate that he interviewed at least 91 women. One woman recalls: 
We were interviewed by a panel and then we got called back again to be interviewed by the Commissioner, who at that time was Mr Lewis. He would just call you in and talk to you about why you wanted to join. It was just a very general chat for five or 10 minutes or so ... I remember when he asked me about why I wanted to join I talked about doing Juvenile Aid. That was probably the right thing to do at the time when I wasn't aware of it. I was extremely nervous anyway ... I found out later that men didn't go through that process, just the women. ${ }^{53}$

The main purpose of the meetings appears to have been to identify and exclude lesbian 'types'. Yet the concern with the private lives of police officers in general, and women in particular, went wider than homosexual relationships. It has been claimed that selection criteria for both males and females were biased against divorcees and people separated or in de facto relationships. An entry in Lewis's diary made very soon after he became commissioner refers to a 'Conference with top officers re policy on P/Women living in de facto relationships' ${ }^{54}$ There is little doubt that senior officers, some of whom would later be charged with official corruption, were at the same time puritanically opposed to such relationships. Threats of transfer were the most common means of intimidating both women and men. ${ }^{55}$

There was a strong feeling amongst interviewees for this study that there was an unofficial policy of keeping women in traditional areas such as juvenile aid, sexual offences, and in secretarial and clerical functions. In particular, women were disproportionately deployed at the city station and watchhouse: 'the majority of females were spending two to three years there, which meant that those who wanted to go to the country (to gain wider experience for promotion purposes) were being disadvantaged'. ${ }^{56}$ Women were needed primarily to conduct body searches and the dwindling numbers in the early 1980s meant that women were posted there for long periods. ${ }^{57}$

Discrimination also manifested itself in neglect and in the broad discretion left to supervisors to treat women according to the supervisor's own prejudices. The following description of conditions in the Rape Squad in this period demonstrates the kind of ghetto environment many women worked in. It also shows how a specialist squad, one that had been established by Whitrod to better address the trauma of women victims, came also to trap women police in a distressing work environment.

When I was working in the Rape Squad we weren't very well looked after and we worked under atrocious conditions but we were necessary and we were an all female squad so in that sense we were fairly unique. We didn't have any office or anything like that. We'd interview, we'd talk to rape victims in amongst this huge information bureau system. Phones are ringing and things like that. We had to work on our own. If we were seen talking to each other, talking on the job, we were seen not to be working. So therefore they would give us jobs answering the phones and doing motor vehicle checks and things like that. We had quite a few women that left and went out on stress recovering in a psychiatric ward for a couple of weeks just for a break, they had a break down. But I didn't realise at that time it was a fairly tough area. Women wouldn't go into it because of the reasons I just outlined so it was difficult to get out as well. I was there for three years on what was supposed to be a temporary transfer. ${ }^{58}$ 
In fact, squad members were expected to do little more than conduct interviews and provide victim support. The more prestigious duties of investigation and prosecution were then handed over to male detectives. ${ }^{59}$

Within a decade of the so-called 'Camelot' reforms of the early 1970s, women had again been pushed to the margins of policing in Queensland and were to remain neglected until the early 1990s. It was only when the constant accusations of corruption in the police force finally erupted into an independent commission of inquiry (1987-89) that neglect and discrimination of women was investigated in a wider public forum. The Fitzgerald inquiry reported that high level police corruption had been encouraged by maladministration in both the police and government. In addition to reforms in the organisation, administration and training of police, Fitzgerald recommended that female quotas be abandoned in favour of recruitment (and promotion) by merit. Fitzgerald's recommendations were reflected in the Police Service Administration Act (1990) passed by the Labor government that came to power following the revelations of the inquiry. Immediately, five women received promotions to inspector level and there was a rapid increase in the number of female recruits which trebled to over $30 \%$ of the intake into the academy. Once again, as with the Whitrod years, women were seen as the harbingers of positive cultural change within policing and as a bulwark against 'old guard' corruption. ${ }^{60}$

The history of women in the Queensland Police from 1970 to 1987 is the story of a sudden opening of opportunities for women followed by a rapid reversal of status, and a longer period of decline and marginalisation. The story provides a number of important lessons when considering the policy implications for successful change in the conditions of women police. First, the formal means of protection from discrimination is a necessary step, although not sufficient in itself, to ensure equality of opportunity. The discretion held by senior male officers in personnel decisions are closely related to the exercise of bias against women. In traditionally authoritarian and patriarchal organisations like the police, men are unlikely to share power with women unless required to by legislation. ${ }^{61}$ Indeed, even when adhering to EEO guidelines, it is likely to be the letter of the law that is observed rather than the spirit. ${ }^{62}$

In the Whitrod period, the commissioner's discretionary power was exercised in favour of women but such progressive opportunities for women police were dependent on his continued tenure of office and on the shifting and ambivalent commitment of the police union to equality for women. Even if recourse to equal opportunity and anti-discrimination legislation had been available at the state level in the 1970s and 1980s, it would have been of only limited assistance to the small numbers of women who were attempting to gain a foothold in policing. They would have needed to rely on the vagaries of seeking individual legal redress for what amounted to a collective problem for women. ${ }^{63}$ Such complaint-based legislation also required strong (and brave) individuals willing to confront oppressive conditions. Even when complainants saw themselves as representing 'all women', the outcomes were more likely to benefit the individual. Nevertheless, anti-discrimination legislation was an important step because, as Thornton notes, women for the moment needed the power of the state, despite its 'fickleness', to redress imbalances of power. The legislation also had important symbolic value: 
Anti-discrimination legislation does represent a halting step towards formal recognition of the fact that white, Anglo-Celtic, heterosexual, able bodied men have power in our society and that they will invariably exercise it in their own interest ... A shadowy framework for a modicum of social change has therefore emerged. ${ }^{64}$

Although necessary, anti-discrimination legislation inevitably leaves spaces for less direct forms of discrimination. Some discretion usually remains for officialdom to engage in management practices that marginalise women. A principle of 'rational bias' operates in organisations in which lower-level decision makers act on cues from their superiors about which decisions are favoured and are likely to be rewarded, and thus discriminatory practices can be very difficult to identify and counter. ${ }^{65}$

Today, many policewomen remain ambivalent about the necessity for affirmative action and anti-discrimination policies. Powerful features of police culture combine with the women's own perceptions of threat from within the organisation, causing them to view recourse to such measures as a sign of weakness. They hold the view that 'female cops' should be able to look after themselves (by themselves). ${ }^{66}$

The second important point therefore concerns the types of support services established for women when opportunities are opened: opportunities created both through their own efforts and supportive elements within the organisation. The aftermath of the Whitrod reforms in the 1970s shows that simply opening doors for women is not enough. Problems of informal opposition and indirect discrimination will be compounded by the obligations of child-rearing and home-making placed on women. Given the diversity of obstacles to their career advancement, a comprehensive policy of support for women is needed. Some needed EEO measures include: extended paid maternity leave and in-house child care assistance; more women on selection panels and policy making bodies; career development assistance in the form of organised mentoring and career advice; and encouragement to undertake in-service training. Support networks and counselling groups need to be encouraged; education about sex discrimination and sexual harassment is vital given the continuing ambivalence and uncertainty of many women themselves about these matters. At management levels there needs to be clear dissemination of EEO policies with managers being held responsible for policy implementation; and close monitoring of implementation. ${ }^{67}$

The impetus for concerted efforts in these areas must come from women. This is, admittedly, asking a lot from employees in police organisations which, despite periodic organisational and administrative reforms, typically remain authoritarian in many ways. It is doubly difficult in view of the fact that many survival strategies developed by women police over time, strategies variously called the 'neutral-impersonal' or the 'professional officer', have been constructed by them to purposely avoid drawing attention to themselves. ${ }^{68}$

However the third important conclusion is that women must become familiar with the political agendas into which they are inevitably drawn under different regimes. During times of progressive change in particular, the expectations placed upon women are often unrealistically high and tend to be designed to fulfil the agendas of powerful males within the organisation. Reformers portray attempts to 'feminise' law enforcement as a progressive move, usually designed to provide a 'human face' for 
organisational practice. ${ }^{69}$ Seen in this light, women are 'allowed in' at particular historical points when agencies wish to relegitimise their practices (for example, the introduction of community policing). When more reactionary regimes come to power, or even when the first flush of reformist zeal has abated, women must then confront the inevitable backlash because of the expectations loaded onto them as part of the ongoing politics of policing.

Recently Queensland advanced to the point of introducing EEO requirements for the public sector. Nonetheless, many of the old discriminatory attitudes persist and EEO policies do not occupy a central place in the vision of the current police administration. On the other hand, in the immediate post-Fitzgerald environment, there emerged again the unrealistic expectations in some quarters that women might 'civilise' the organisation, a view reminiscent of Whitrod's expectations in the early 1970s. It is unlikely that the (renamed) Queensland Police Service will return to the dark misogynist years from 1976 to 1987, but the new wave of female recruits face many of the same problems that challenged and damaged their pioneering sisters. It is therefore essential to learn from the past. Determined efforts, particularly by women police themselves, are needed to ensure that women are able to maximise their contribution to police work and receive the full rewards of their commitment to careers in law enforcement and community service.

\section{Endnotes}

1 A variety of sources was used for this study including interviews, newspaper articles, inquiry and review reports, and internal police reports, memos and letters (supplied by the Queensland Police Service). Extracts from former Commissioner Lewis's diaries were obtained under Freedom of Information. Most documentary sources are official and leave gaps in the subject. Consequently, interviews were used as a second major source to supplement documentary evidence. Nineteen persons were consulted or interviewed. The large majority were policewomen. Some informants simply provided clarification or a small amount of information over the telephone. Others provided lengthy taped interviews. Many of those interviewed were significant players in the events described and serve as key informants. Others were more the recipients of policy decisions. Obviously, a degree of subjectivity is inevitable in these accounts. Wherever possible, verification has been sought from other sources.

2 F. Heidensohn, Women in Control?: The Role of Women in Law Enforcement, Oxford, 1992; S. Martin, On the Move: The Status of Women in Policing ，Washington DC, 1990; S. Jones, Policewomen and Equality, London, 1986.

3 J. Balkin, 'Why Policemen Don't Like Policewomen', Journal of Police Science and Administration, vol. 16, no. 1, 1988.

4 J. Hunt, 'The Logic Of Sexism Among Police', Women and Criminal Justice, vol. 1, no. 2, 1990.

5 M. Brown, 'The Plight Of Female Police: A Survey of NW Patrolmen', Police Chief, vol. 61, no. 9, 1994.

6 T. Austin and D. Hummer, “"Has A Decade Made A Difference?” Attitudes Of Male Criminal Justice Majors Towards Female Police Officers', Journal of Criminal Justice Education , vol. 5, no. 2, 1994.

7 M. Yeagher and N. Yentes, 'Choosing A Career In Policing: A Comparison Of Male And Female Perceptions', Journal of Police Science and Administration , vol. 14, no. 4, 1986; A. Worden, 'The Attitudes of Women And Men In Policing: Testing Conventional and Contemporary Wisdom', Criminology, vol. 31, no. 2, 1993.

8 K. Love and M. Singer, 'Self-Efficacy, Psychological Well-Being, Job Satisfaction And Job Involvement: A Comparison of Male and Female Police Officers', Police Studies, vol. 11, no. 2, 
1988.

9 Worden, op. cit.

10 Heidensohn, op. cit; Martin, op. cit.; Lunneborg, op. cit.

11 Heidensohn, op. cit .

12 For example see, A. Halford, No Way Up the Greasy Pole , London, 1993.

13 J. Daum and C. Johns, 'Police Work From a Woman's Perspective', Police Chief, vol. 61, no. 9, 1994.

14 Heidensohn, op. cit

15 C. Bulbeck, 'The Hegemony Of Queensland's Difference', Journal of Australian Studies, vol. 21, 1987; P. Putnis, 'The Construction Of Queensland: Historical And Contemporary Perspectives', Journal of Australian Studies, vol. 25, 1989.

16 D. Jaensch, 'The "Bjelke-mander”' in A. Patience (ed.), The Bjelke-Petersen Premiership 19681983: Issues in Public Policy, Melbourne, 1985.

17 Putnis, op. cit.

18 P. Coaldrake, Working the System: Government in Queensland, Brisbane, 1989; P. Dickie, The Road to Fitzgerald and Beyond , Brisbane, 1989.

19 R. Whitrod, 'Some Problems of Police Ethics', Canberra Bulletin of Public Administration, vol. 56, 1988, p. 40.

20 R. Whitrod, Correspondence with the authors, September 5, 1992.

21 Whitrod, 1992, op. cit.

22 P. Hazel, 'Queensland Policewomen's 50th anniversary', unpublished paper, Brisbane, 1981; Commissioner's Newsletter, Brisbane, no 207 \& 216, 1972 \& 1976.

23 Whitrod, 1988, op. cit., p. 40.

24 Interview 2.

25 Ibid.

26 Interview 3.

27 Letter, general secretary, Queensland Police Union, to commissioner, 14 September 1970.

28 Letter, general secretary to Bauer, 4 December 1969.

29 Deputation by executive, QPU, to commissioner, 13 October 1972, pp. 3-4.

30 Interview 1

31 Commissioner's Correspondence, September to December 1973.

32 Sunday Sun, 11 June 1972. Gotto was a former prime minister's staff member whose name, in Australia, was used at the time to refer in a negative or facetious manner to a woman who was young, attractive and successful

33 Notes, Commissioners' Conference, Darwin, June 1976

34 Interview 1.

35 W.R. Johnston, The Long Blue Line: A History of the Queensland Police , Brisbane, 1992, pp. 284-5.

36 Past and Present Policewomen's Association of Queensland, Submission to Commission of Inquiry into Possible Illegal Activities and Associated Police Misconduct , Brisbane, 1987, pp. 7-16.

37 Dickie, op. cit., pp. 1-48, 233-37; G. Fitzgerald, Report of a Commission of Inquiry into Police Misconduct and Associated Activities , Brisbane, 1989, pp. 30-78.

38 Interview 4.

39 Notes, Commissioners' Conference, 1989.

40 Interview 8.

41 For example see Sunday Sun, 2 December 1973; Queensland Police Journal, May 1971, p. 36, July, p. 2.

42 Interview 6.

43 T. Lewis, Diaries, Brisbane, Criminal Justice Commission, 12 September 1977.

44 Criminal Justice Commission, Report by the Honourable R.H. Matthews QC on his Investigation into the Allegations of Lorrelle Saunders Concerning the Circumstances Surrounding Her being Charged with Criminal Offences in 1982, and Related Matters , vol. 1, Brisbane, p. 70, 1982.

45 Interview 5.

46 Whitrod, 1992, op. cit.

47 Johnston, op. cit., p. 285.

48 Interview 2.

49 N. Fielding and J. Fielding, ‘A Comparative Minority: Female Recruits To A British Constabulary 
Force’ Policing and Society, vol. 2, no. 2, 1992; Hunt, op. cit.

50 Courier Mail, 4 June 1993, p. 3.

51 Interview 2.

52 National Times, 27 February 1978, p. 13.

53 Interview 6.

54 Lewis, op. cit., 17 December 1976.

55 Interview 6.

56 'The Watchhouse Situation', Past and Present Policewomen's Association of Queensland Magazine, vol. 2, no. 3, p. 4.

57 Interview 6.

58 Interview 6.

59 Interview 7.

60 Fitzgerald, op. cit., p. 246.

61 E. Hochstedler, 'Impediments To Hiring Minorities In Public Police Agencies', Journal of Police Science and Administration, vol. 12, no. 2, 1984; Jones, op. cit.; Weisheit, op. cit.; Martin, op. cit.; E. Nelson, “'Employment Equity” and the Red Queen’s Hypothesis: Recruitment and Hiring in Western Canadian Municipal Police Departments', Canadian Police College Journal , vol 16, no. 3, 1992.

62 G. Felkenes, P. Peretz and J. Schroedel, 'An Analysis of the Mandatory Hiring of Females: The Los Angeles Police Department Experience', Women and Criminal Justice, vol. 4, no. 2, 1993.

63 M. Thornton, The Liberal Promise: Anti-Discrimination Legislation in Australia , Melbourne, 1990.

64 Ibid, pp. 261-62.

65 Hochstedler, op. cit. p. 238; Martin, op. cit, p. 92.

66 K. Wimshurst, 'Anticipating the Future: A Comparison of the Early Experiences and Career Expectations of Male a Female Police Recruits', Australian and New Zealand Journal of Criminology, in press.

67 Martin, op. cit., pp. 166-71; T. Prenzler, Women in Policing: Policy Implications From the US Experience, Brisbane, 1992, pp. 16-19.

68 P. Jacobs, 'How Female Police Officers Cope With A Traditionally Male Position', Sociology and Social Research, vol. 72, no. 1, pp. 4-6; J. Wexler, 'Role Styles of Women Police Officers', Sex Roles, vol. 12, no. 7/8, 1985.

69 K. Laster and R. Douglas, 'Feminized Justice: The Impact of Women Decision Makers in the Lower Courts in Australia', Justice Quarterly, vol. 12, no. 1, 1995. 